\title{
Inclusive Education: Cooperation Between Class Teachers, Special Teachers, Parents to Optimize Development of Special Needs Childrens
}

\author{
Alpha Ariani1,a, Mochamad Wahyudi2,b, Rugaiyah ${ }^{1, c}$ \\ ${ }^{1}$ Departemen of Education Management, Universitas Negeri Jakarta, Jl. Rawamangun Muka, Jakarta 13220, Indonesia \\ ${ }^{2}$ STMIK Nusa Mandiri Jakarta, Jl. Damai No. 8, Margasatwa, Jakarta, Indonesia \\ E-mail: a alphaariani_mp15s3@mahasiswa.unj.ac.id; b wahyudi@nusamandiri.ac.id; c rugaiyah@unj.ac.id; \\ ${ }^{*}$ Corresponding Author
}

How to Cite : Ariani, A., Wahyudi, M., Rugaiyah, R. (2019). Inclusive Education: Cooperation Between Class Teachers, Special Teachers, Parents to Optimize Development of Special Needs Childrens. International Journal for Educational and Vocational Studies, 1 (5), 396-399

\section{ARTICLE HISTORY}

Received:16 July 2019

Revised: 21 August 2019

Accepted: 22 September 2019

\section{KEYWORDS}

Inclusive Education,

Special Teacher,

Collaboration

\section{ABSTRACT}

This study aims to find out the collaboration between class teachers, special guidance teachers, and parents of children with special needs. In addition, it also knows the optimization of the developmental aspects of children with special needs which include academic attitudes, social skills, emotions, and independence. This study used qualitative research methods. The process of data collection is done using the method of interviews, observation, and documentation study. Data analysis using the model presented by Miles and Huberman includes the process of data reduction, data presentation, and drawing conclusions based on facts in the field. The results of the study show that good collaboration between classroom teachers, special guidance teachers, and parents in the process of education in schools strongly supports the development of children with special needs. The development of aspects of social skills is more prominent than the development of aspects of academic attitudes, emotional development, and independence.

This is an open access article under the CC-BY-SA license.

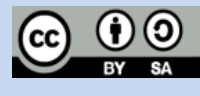

\section{INTRODUCTION}

Inclusive education is a new breakthrough in the world of education that provides opportunities for children with special needs to get quality education services, together with regular children his age. According to Sapon-Shevin O'Neil, the inclusive education service system requires that all children with special needs be served in the nearest schools, in regular classes together with their age friends (Garnida, 2015). Children with special needs are children who have special characteristics or barriers that are different from their age children which shows the mental, intellectual, social, emotional, or physical inability (Mudjito, 2012) (Rachmayana, 2013). Therefore they need educational services that are appropriate to their needs and characteristics.

The aim of inclusive education is for children with special needs to get quality education to optimize all their potential and skills so that they grow into independent individuals (Kustawan \& Meimulyani, 2013), (Divine, 2013). Therefore it needs serious handling from various parties such as schools (especially principals, class teachers, special counselors), parents, government, and the community. All relevant parties are responsible for the development of these children.

In the context of inclusive education, the existence of a special guidance teacher (SGT) is very necessary to help classroom teachers provide services to children with special needs so that they are maximized in the learning process. SGT has special competencies so that it can serve according to the needs of these children (Paul: 2012). In accordance with the Governor of South Kalimantan Regulation No. 65 of 2012 and technical guidelines for the implementation of inclusive education in South Kalimantan Province, the minimum qualification of SGT is the Extraordinary Education (S1) Bachelor (orthopedagog).

Practices in inclusive education, children with special needs and regular children mingle learning, play together in one class. This requires cooperation between the classroom teacher and the supervising teacher specifically in providing assessment, compiling individual learning programs (ILP), as well as giving remedies or enrichment (Rahmaniar, 2016) and (Rudiyati, 2005). But in reality 
there are often misunderstandings about the role of the special counselor in the school. Children with special needs that should also be the responsibility of the class teacher, are left entirely to special counselors by reason of lack of knowledge about children with special needs and skills in dealing with and teaching children with special needs (Fitria, 2012) and (Jurkowski, 2018).

In addition to the school, parents essentially have the main responsibility in the education of their children. Limited time, energy, and limited knowledge make parents have to ask for help from other parties (schools) in the education process of their children. However, it does not mean that parents give up their responsibilities at school, given the active involvement of parents is very important in learning and developing children with special needs (Chao, 2018) and (Sugiarti, 2013). Knowing the importance of collaboration between class teachers, special counselors, and parents for the development of children with special needs, the main question of this research is how the collaboration takes place and its relation to the development of academic attitudes, social skills, emotions, and independence of children with special needs.

\section{METHODS}

This study uses a qualitative descriptive approach with a focus on student management and development of children with special needs. The research was conducted in five elementary schools that provided inclusive education in the city of Banjarmasin, South Kalimantan, namely SDN Banua Anyar 8, SDN Banua Anyar 4, SDN Gadang 2, SDN-SN Sungai Miai 5, and SDN Kuin Selatan 3. The participants in this research consisted of five principals, ten class teachers, eleven special teachers, and ten parents of students. Participation is determined by purposive sampling technique, namely, the subject directly related to the education process of children with special needs. Data collection was done through documentation, questionnaire, direct observation, interviews for three months starting from January till March 2018. Data analysis techniques used are data reduction, data display, and conclusion drawing/verification (Sugiyono:2014). Specific data analysis aims to find out the cooperative relationship between class teachers, special teachers, and parents. In addition, it also knows the development of students with special needs which includes the development of academic, emotional, social skills, and independence attitudes. The researcher triangulated data sources and techniques to get valid data.

\section{RESULTS AND DISCUSSION}

\subsection{Collaboration between class teachers, special guidance teachers (SGT), and parents}

Special guidance teachers build coordination with class teachers and parents of children with special needs.
Coordination with classroom teachers is carried out in terms of the learning process, subject matter, and assessment of student learning outcomes. If the teacher with special needs prepares the PPI, it will coordinate with the class teacher so that the learning is more systematic in accordance with the characteristics and abilities of the child. But if you do not make a PPI, the ABK follows the same learning material as regular students, and if you have to complete the assignment, the special tutor will assist and assist in accordance with the child's abilities.

Coordination with parents is carried out in terms of providing information about children's development, learning processes and materials in class, assignments, or children's needs in the learning process related to understanding and responsibility for school assignments that are still relatively low. But in all the schools studied, coordination on this matter was only carried out by a special counselor. While class teachers coordinate intensively only with parents of regular students. This is because according to those who understand the situation better and the development of children with special needs is a special counselor.

All tutors specifically coordinate with parents via SMS, WA, or verbally when picking up or delivering children. Only a few shadow teachers use connecting book media to convey children's needs in the learning process, convey child development, and other special events. This connecting book is a special tutor's diary about students' behavior in class and abilities that have been achieved by students (Rahmaniar, 2016) and (Zakia, 2015). Based on this record, the teacher can make a report on the progress of the child at the end of the semester through the process of analyzing synthesis and interpretation. If the teacher's record is incomplete, it is feared that the results of the report will be subjective and based on mere guesswork.

\subsection{Development of academic attitudes, social skills, emotions, and independence}

Four aspects of development that were observed in this study were academic attitudes, social skills, emotions, and independence. Children with special needs show progress during their education in school, even though the development shown is very small, it takes a long time, and sometimes the behavior that is expected to be inconsistent.

When compared between the four aspects studied, the prominent developments are aspects of social skills, then the development of emotions, independence, and the last is academic. Social skills between one child and another vary depending on their characteristics and needs (Diahwati, 2016). But with guidance and school efforts to create an atmosphere of togetherness and diversity between children with special needs and regular children, it allows the imitation of positive behavior in children with special needs. They learn to greet, greet and return greetings, learn to cooperate, play, control themselves, 
and learn to be assertive. If children with special needs have good social skills, they are expected to carry out their social functions so that they are able to manage social problems well and meet their needs.

Secondly, the development of emotional aspects is shown through the child's ability to control anger, express disappointment and anger in a more mature way, not easy to beat, not screaming, and not easy to cry. Positive interactions between teachers and students can improve emotional control learning when children with special needs experience difficult times. The classroom teacher designs the classroom atmosphere well, the special teacher teaches ways to express emotions healthily, and friends give examples so that they can really develop the emotional aspects of children with special needs.

Along with increasing class and age, ABK students have begun to show their independence such as starting to go to the bathroom by themselves, wearing their own clothes or shoes, going home from school on their own, and starting to be able to sit still in class during the learning process. Independence becomes a very important skill to be used as a foothold in overcoming problems as adults. The role of parents is very large in developing children's independence. If parents do not help the independence program implemented by the teacher in the school, the child's independence will not develop. This is because there is more time for parents and children than when the teacher is in school with the child.

Academic attitude becomes a more difficult aspect to develop compared to the other three aspects. This is because the main disruption of children with special needs is in non-adaptive behavior. If non-adaptive behavior can be overcome through conditioning the environment, the child will be able to focus on subject matter that involves a lot of cognitive. The role of teachers and parents is very important and needed to maximize children's potential.

\subsection{Collaboration between parents-special guidens teacher -parents and the development of children with special needs}

Schools that succeed in establishing good cooperation between classroom teachers, special guidance teachers and parents will be able to create good learning in the classroom. All work together to provide services in accordance with the characteristics and needs of children so that children achieve optimal development. Everything that is taught in school is also applied at home so that the formation of behavior, attitudes and knowledge becomes more stable. Children with special needs at the school showed better development in academic attitudes, social skills, emotions and independence than in schools where the cooperative relationship was less effective.

\section{CONCLUSION}

The success of the implementation of inclusive education is reflected in the development achieved by children with special needs. Collaboration between class teachers, special guidance teachers, and parents of students with special needs is one of the factors that contribute to this success. Class teachers and tutors specifically work together to develop strategies, learning plans that are in accordance with the characteristics or needs of students with special needs and inform parents so that they can be escorted both in school and at home. Everything that is learned and developed at school can be repeated at home by parents. The development of social skills is the most prominent aspect of its development compared to the aspects of emotion, independence, and academic attitudes.

\section{REFERENCES}

Ajuwon, Paul M. (2012). General Education Pre-Service Teachers Perceptions of Including Students With Disabilities in their Classrooms. 012. International Journal Of Special Education. Vol. 27, No. 3, pp. 100-107. https://eric.ed.gov//id=EJ1001063.

Chao, C. Nuo, G., F. Tsz, T. Lai, M. Ji, and S. Kai. (2018). "Which inclusive teaching tasks represent the highest level of teacher efficacy in primary and secondary schools?" Teach. Teach. Educ., Vol. 75, p. 164-173. https://doi.org/10.1016/j.tate.2018.06.014

Fitria, Rona. (2012). The Learning Process in Setting Inclusion in Primary Schools. E-JUPEKhu (Special Educational Scientific Journal). Vol. 1, No. 1, pp. 90-101. http://ejournal.unp.ac.id/index.php/jupekhu

Garnida, Dadang. (2015). Introduction to Inclusive Education. Bandung: Refika Aditama.

Divine, M.T. (2013). Inclusive Education: Concepts and Applications. Yogyakarta: Ar-Ruzz Media., P. 20.

Jurkowski, S. and Müller, B. (2018). Co-teaching in inclusive classes: The development of multi-professional cooperation in teaching dyads. Teach. Teach. Educ, 75 (1), 224-231. https://doi.org/10.1016/j.tate.2018.06.017

Kustawan, D. and Meimulyani, Y. (2013). Know Special Education and Special Services Education and Implementation. Jakarta: Luxima Metro Media., P. 22.

Mudjito, et al. (2012). Inclusive Education. Jakarta: Banduose Media, p. 25.

Technical Guidelines for Implementing South Kalimantan Provincial Inclusive Education. (2013). p. 48.

R. Diahwati, Hariyono, F. Hanurawan. (2016). Social Skills of Students with Special Needs in Inclusive Elementary Schools. Journal of Education: Theory, 
Research, and Development, Vol. 1 No. 8, pp. 1612-1620.

R. Sugiarti, U.S. Personal. (2013). Factor Analysis Affecting the Success of Slow Learner Student Learning at Semarang State Special Schools (SLB). Jurnalwacana.psikologi.fk.uns.ac.id.

Rachmayana, D. (2013). Among Inclusive Extraordinary Education Towards Future Children. Jakarta: PT. Luxima Metro Media, p. 19.

Rahmaniar, F.A. (2016). The Duty of Special Companion Teacher (GPK) in Providing Educational Services for Students with Special Needs in Inclusive Schools in SD Negeri Giwangan Yogyakarta. Widia Ortodidaktika Journal, 5 (1), 1252-1263.

Rudiyati, S. (2005). Roles and Tasks of Special Advisory Teachers "Special Resources Teachers" in Integrated Education / Inclusion. Journal of Special Education, 1 (1), 17-33.

Sugiyono, (2014). Management Research Method. Bandung: Alfabeta, p. 404. 